\title{
Effects of a large herbivorous gastropod on macro- fauna communities in tropical seagrass meadows
}

\author{
Allan W. Stoner, Melody Ray, Janice M. Waite \\ Caribbean Marine Research Center, 805 East 46th Place, Vero Beach, Florida 32963, USA
}

\begin{abstract}
A 10 mo field experiment in seagrass meadows of the Exuma Cays, Bahamas, indicated that grazing by queen conch Strombus gigas L. had an important effect on the abundance of seagrass detritus (an important conch food) and the structure of macrofauna communities. At 2 sites where conch were abundant, conch exclosures always contained higher (to $97 \times$ ) quantities of detritus than enclosures of conch at high density $\left(1.2 \mathrm{conch} \mathrm{m}^{-2}\right)$ typical of values found in the field. No significant effects were observed on living seagrass biomass, shoot count, or growth, nor on epiphyte biomass. Epiphyte loads were relatively low and apparently caused no reduction in seagrass growth as a result of shading. Density of epibenthic macrofauna ranged from 799 to 6610 individuals $\mathrm{m}^{-2}$ (mostly tanaids, amphipods and ostracods), and conch exclosures always contained higher (to $3.8 \times$ ) densities than enclosures of conch at high density. A positive correlation was observed between macrofauna density and detritus. At the end of the experiment at one site, exclosures had at least twice the number of species per sample as any of the enclosures. Relative compositional differences among the 211 different species encountered during this study were subtle; however, except for a few species, absolute numerical differences were higher in the exclosures than in the high density enclosures. Largest increases in density associated with increases in seagrass detritus occurred in tube-building tanaidaceans and freeliving amphipods and ostracods. Results from this study suggest that conch strongly affect community structure by consuming detritus, an important component of the overall vegetative structure that provides food and shelter for other benthic invertebrates. Variation in dynamics of seagrass communities may be a function of large herbivores and detritivores.
\end{abstract}

KEY WORDS: Seagrass $\cdot$ Herbivory $\cdot$ Strombus gigas $\cdot$ Plant-animal $\cdot$ Macrofauna $\cdot$ Community $\cdot$ Diversity. Bahamas

\section{INTRODUCTION}

Large herbivorous invertebrates and fishes have significant effects on the composition and standing crops of macroalgal communities in coral reef and seagrass habitats. Urchins and fishes are responsible for the bare sand halos that form at the interface between these 2 habitats (Randall 1965, Ogden et al. 1973, Tribble 1981, Hay 1984, Liddell \& Ohlhorst 1986, Carpenter 1988), and large aggregations of sea urchins (Dean et al. 1984) and queen conch (Stoner 1989a) are known to reduce the biomass of macroalgae in their paths.

Although the vast majority of seagrass inhabitants do not consume living seagrasses (Kikuchi 1980, Thayer et al. 1984), seagrass detritus is often the food-web base in seagrass habitats (Zimmerman et al. 1979, Kikuchi 1980, Vadas et al. 1982, Zieman et al. 1984.
Stoner 1989b). Living and senescent seagrass blades as well as decaying seagrass detritus also provide shelter for inhabitants of seagrass meadows, and plant structure is known to influence predation rates (Cooper \& Crowder 1979, Heck \& Thoman 1981, Heck \& Wilson 1987, Heck \& Crowder 1991). As a result, densities of epibenthic macrofauna are often directly correlated with amount of plant biomass (Heck \& Wetstone 1977 , Stoner 1980, Homziak et al. 1982, Ansari et al. 1991). Heck \& Orth (1980) identified seagrass habitat complexity as 'the single most important factor influencing changes in faunal composition' and hypothesized that macrofauna compete for shelter by interfering with one another's ability to secure protection.

The effects of predation on macrofaunal community structure are well documented (e.g. Connell 1975, Gilinsky 1984, Summerson \& Peterson 1984, Ojeda \& 
Dearborn 1991), as are the effects of herbivory on marine plants (Paine \& Vadas 1969, Lawrence 1975, Lubchenco \& Gaines 1981, Carpenter 1986, Horn 1989, Hay 1991). Little attention, however, has been given to the indirect effects of herbivory on macrofauna communities, except in the context of sea urchin/fish interactions (Carpenter 1988, 1990, Hughes 1994). This experiment was conducted to test the hypothesis that grazing by the large herbivorous/detritivorous gastropod Strombus gigas (queen conch) has a significant effect on macrofauna community structure in seagrass meadows as well as an effect on macrophytes (Stoner 1989b).

The primary foods of queen conch are seagrass detritus, seagrass-colonizing epiphytes, and other macroalgae, but not the living seagrasses themselves (Randall 1964, Stoner \& Waite 1991). To test the hypothesis that removal of detritus and macroalgae by conch influences the abundance and species composition of smaller macrofauna, we manipulated densities of juvenile conch in field enclosures. We also hypothesized that reduction of epiphyte standing crops by conch grazing would increase above-ground growth of seagrass. Epiphyte growth can inhibit seagrass growth by shading the blades (Bulthuis \& Woelkerling 1983, van Montfrans et al. 1984). Epiphyte grazers have been shown to increase productivity and growth in the seagrass Halodule wrightii (Howard \& Short 1986); we predicted a similar indirect effect of queen conch on productivity of Thalassia testudinum.

\section{MATERIALS AND METHODS}

The Exuma Cays island chain in the central Bahamas lies between Exuma Sound and the shallow Great Bahama Bank, with numerous tidal inlets connecting the waters of the sound and bank (Fig. 1). Juvenile queen conch aggregations cover surface areas up to 600 ha and are commonly found year after year along the flow fields created in these tidal channels (Wicklund et al. 1991, Stoner et al. 1994). Most aggregations are located within $5 \mathrm{~km}$ of inlets on the bank side near sand bars in moderate density seagrass (Thalassia testudinum) (Stoner et al. 1995), and densities of 0.1 to 1.6 conch $\mathrm{m}^{-2}$ are common (Stoner \& Ray 1993). One and two yr old juvenile queen conch are capable of choosing optimal seagrass habitat, preferring moderate density seagrass over high or low density (Stoner \& Waite 1990).
Two aggregations were selected for study near the Caribbean Marine Research Center field station on Lee Stocking Island (Fig. 1). The CBC (Children's Bay Cay) aggregation occupied moderate density Thalassia testudinum in an area of strong reversing tidal current and has been studied since 1984 (Wicklund et al. 1991). The NBC (Neighbor Cay) aggregation, a much smaller and ephemeral beach aggregation, occupied sparse $T$. testudinum in a leeward island cove $8 \mathrm{~km}$ northwest of Lee Stocking Island. Both study sites were on the bank and had been used for investigations on conch feeding (Stoner \& Waite 1991).

Queen conch densities were manipulated at $\mathrm{CBC}$ and NBC in 2 random blocks of 4 treatments at each site. Treatments were 0 -conch, low density conch (0.6 ind $\mathrm{m}^{-2}, 10$ individuals), high density conch (1.2 ind $\mathrm{m}^{-2}, 20$ individuals), and open plots, representing the range of juvenile conch densities found in nursery sites in the Exuma Cays (Stoner \& Waite 1990, Stoner \& Ray 1993). Exclosures for the 0-conch treatment and enclosures for the low and high density conch treatments were circular pens $(r=2.3 \mathrm{~m}, \mathrm{~h}=$ $0.25 \mathrm{~m}$ ) made from green, vinyl-covered wire mesh $(25 \times 50 \mathrm{~mm})$. The mesh was secured to reinforcement bars which were driven into the sediment, pulling the enclosure wall $\sim 3 \mathrm{~cm}$ beneath the substrate to prevent conch from escaping. The open plots were delineated only with reinforcement bars, no wire mesh, to allow access by wild conch. Water depth at mean low water was $3.2 \mathrm{~m}$ at $\mathrm{CBC}$ and $1.2 \mathrm{~m}$ at $\mathrm{NBC}$. Individual pens were separated by at least $2 \mathrm{~m}$, and blocks were separated by at least $40 \mathrm{~m}$. An effort was made to place experimental plots in areas of similar seagrass and detrital cover.

At the beginning of the experiment, mean wild conch density among the treatment plots was 0.60

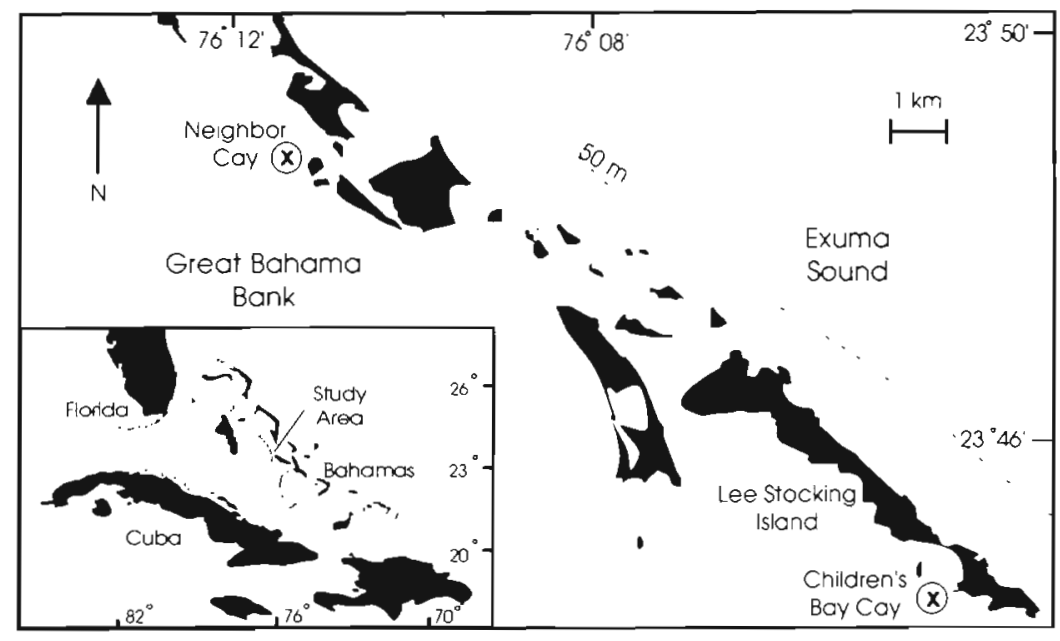

Fig. 1. The 2 study sites at Children's Bay Cay $(\mathrm{CBC})$ and Nejghbor Cay (NBC), in the Exuma Cays, Bahamas 
$(\mathrm{SD}=0.20)$ conch $\mathrm{m}^{-2}$ at $\mathrm{NBC}$ and $0.23(\mathrm{SD}=0.14)$ conch $\mathrm{m}^{-2}$ at $\mathrm{CBC}$. Animals were removed from all but the open plots. To provide an index of grazing pressure at the 2 sites, conch density was measured in the open plots every 2 to $3 \mathrm{wk}$, and once per month in 3 circles $\left(19.6 \mathrm{~m}^{2}\right)$ placed haphazardly around the general experimental areas.

Experimental conch were collected from around the enclosures at each site, measured, tagged, and distributed among the enclosures in 1989 on April 3 (NBC) and April $7(\mathrm{CBC})$. The size range of these animals, 90 to $130 \mathrm{~mm}$ in shell length, represented the natural range commonly found. Every 2 to $3 \mathrm{wk}$, dead or missing conch were replaced in the enclosures, and newly emerged juveniles were removed from the pens to maintain treatment integrity. Mortality was a problem in only 1 enclosure (high density treatment at $\mathrm{CBC}$ ), where shell-breaking predators attacked conch repeatedly.

Experimental conch were remeasured for shell length 19 to 22 May, 22 to 23 August, and 12 to 15 December 1989. Conch growth was examined only to establish whether or not available resources became limiting. For each of the 3 growth periods, daily growth rates were calculated for each conch that was present at the start of the experiment; growth data for replacements were not analysed.

The following variables were measured in each plot to determine the effects of conch on flora and fauna. Thalassia testudinum (shoot density, green aboveground biomass, detritus weight, and blade growth), biomass of all other macrophytes, epiphyte biomass, and, for macrofauna, species composition and abundance. All measurements, except seagrass growth, were made prior to (13 to 23 March), during (15 to 25 May, and 21 to 30 August), and at the end of the experiment (12 to 15 December 1989). Growth was not measured in December because of the lack of treatment effects in the earlier measurements.

The number of Thalassia testudinum shoots was counted within 3 quadrats $(0.25 \times 0.25 \mathrm{~m})$ placed haphazardly within each plot, and all above-ground parts of seagrasses, macroalgae, and detritus (senescent seagrass blades) within the quadrats were collected into nylon bags ( $3 \mathrm{~mm}$ mesh). Macrophytes were sorted in the laboratory and dried at $80^{\circ} \mathrm{C}$ for $\sim 24 \mathrm{~h}$ to constant weight. Dry-weight biomass $\left(\mathrm{g} \mathrm{m}^{-2}\right)$ was determined for each component. Other macrophytes encountered besides $T$. testudinum included the seagrasses Syringodium filiforme and Halodule wrightii and the green alga Batophora oerstedi; quantities of these species were negligible $\left(<1 \mathrm{~g}\right.$ dry wt quadrat $\left.{ }^{-1}\right)$ and were not considered herein.

For each of the 2 sites, analysis of variance (ANOVA. for random blocks) showed no significant $(p>0.05)$ ini- tial differences in Thalassia testudinum characteristics (shoot density, living biomass, and detrital biomass) among the plot areas before experimental conch were added, except for detritus at NBC (both block and treatment effects were significant, $p<0.05)$. However, mean values for detritus were all $<1 \mathrm{~g}$ dry $\mathrm{wt} \mathrm{m}^{-2}$, and the plot areas were considered equal. There was no apparent accumulation of detritus or drift algae on the enclosure walls, and the similarity of detrital abundance in open plots and in enclosures with natural densities of conch indicated that cage effect was not problematic (see 'Results').

After sampling the experimental plots in December 1989, the exclosures creating the 0 -conch treatment were removed except for the vertical supports, allowing wild conch to recolonize the plots. The open and previously protected plots were sampled again for macrophytes 3 wk later to further examine the role of grazing by conch.

Seagrass growth was estimated for each treatment according to Zieman (1974). Each Thalassia testudinum blade was stapled $20 \mathrm{~mm}$ above the sediment in 2 quadrats per treatment. Quadrats of $25 \times 25 \mathrm{~cm}$ were used at NBC. At CBC, where seagrass shoot density was higher, $20 \times 20 \mathrm{~cm}$ quadrats were used in March and May, and $16 \times 16 \mathrm{~cm}$ quadrats were used in September when growth was highest. After 11 to $18 \mathrm{~d}$ of growth, the blades were clipped $20 \mathrm{~mm}$ above the sediment. These harvests were made from 28 March to 4 April, 6 to 9 June, and 8 to 12 September New growth was separated in the lab and weighed for the calculation of growth in $\mathrm{g}$ dry $\mathrm{wt} \mathrm{m}^{-2} \mathrm{~d}^{-1}$.

Epiphyte loads on seagrass blades were estimated by collecting 20 Thalassia testudinum blades haphazardly from each plot and immediately preserving them in $5 \%$ formaldehyde-seawater mixture. In the laboratory, samples were sieved and transferred briefly into $10 \%$ phosphoric acid to remove calcium deposits. Epiphytes were scraped off each blade, and blades and epiphytes were dried separately as described above. Epiphyte loads are expressed as percentages of seagrass weight [epiphyte dry wt $(\mathrm{g}) / \mathrm{T}$. testudinum dry wt $(\mathrm{g}) \times 100$ ]. ANOVA for random blocks showed no significant initial differences in epiphyte loads among treatments $(p>0.5)$ before conch were added.

Macrofauna were sampled by taking 10 core samples (diameter $=7.7 \mathrm{~cm}$ ) haphazardly from each plot; macrophytes and the upper $5 \mathrm{~cm}$ of sediment were collected. In the field, each sample was sieved onto a $0.5 \mathrm{~mm}$ mesh screen and preserved in $5 \%$ formaldehyde-seawater mixture. Motile macrofauna species that potentially used the same epibenthic foods as conch, i.e. epifauna such as crustaceans and gastropods but not polychaetes (which were mostly infaunal 
forms), were extracted by hand from the sediments, identified to the lowest possible taxa (usually species), and counted. At NBC the sediment was medium to coarse sand with $2.7 \%$ organic content (Zones $\mathrm{E}$ and $\mathrm{F}$ in Sandt \& Stoner 1993). At CBC the sediment was fine sand with $3.9 \%$ organics (Zone 5 in Stoner \& Waite 1990). In a previous study at $\mathrm{CBC}$, high densities of conch $\left(8 \mathrm{~m}^{-2}\right)$ did not have significant effects on sediment grain size, total organic content, or chlorophyll (Stoner 1989b), and these characteristics were not reexamined in this study.

To avoid pseudoreplication (Hurlbert 1984), means of the 10 cores per plot were used in statistical analyses. ANOVA for random blocks showed no significant treatment differences ( $p>0.3$ ) in the following variables in March before conch were added: total number of pericarids, decapods, gastropods, and total number of macrofauna. A similar ANOVA design was used for the collections made in May, August, and December. All treatment means, except number of species per sample, were standardized to $\mathrm{m}^{2}$ and transformed $\left[\log _{10}(n+1)\right]$ to improve homogeneity of variance. The

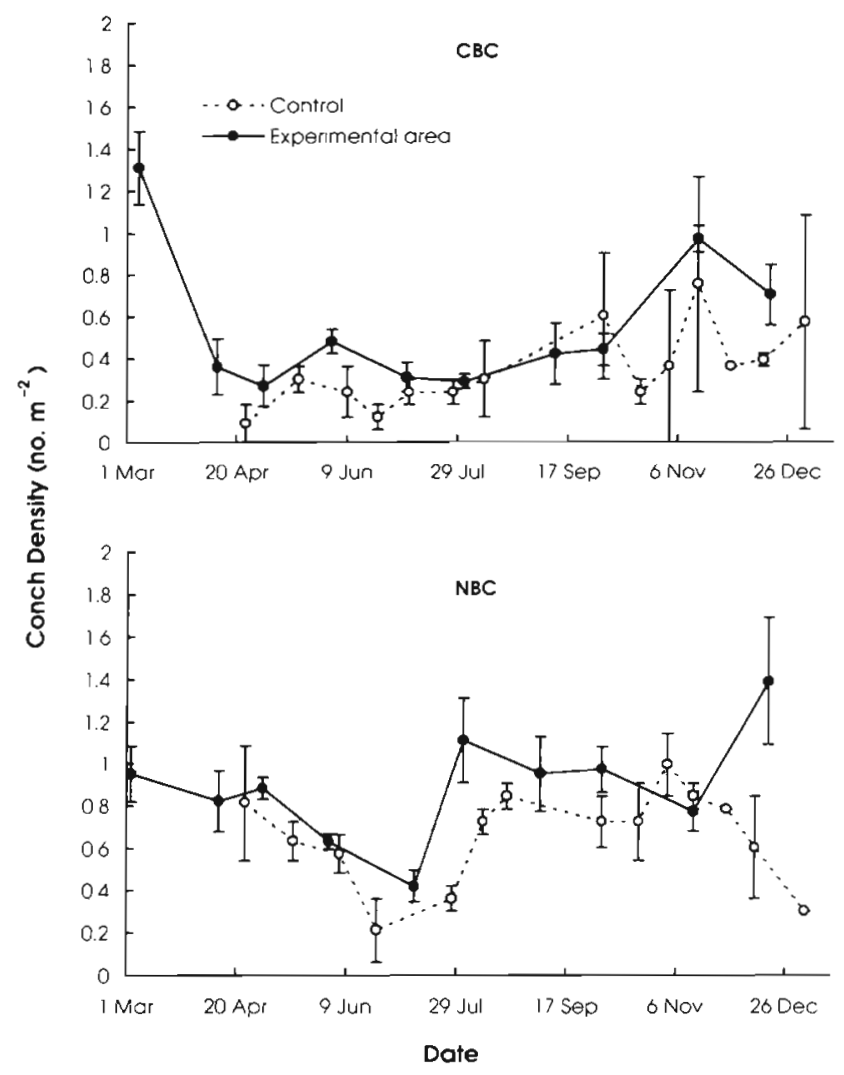

Fig. 2. Strombus gigas. Natural density of juvenile conch (mean $\pm S E$ ) in open, control plots $(n=2)$ and around the general experimental areas $(n=3)$ at 2 study sites from 1 March 1989 to 4 January 1990 relative abundance of species making up $>2 \%$ of total macrofauna was examined at the end of the study period.

The relationships between number of macrofauna, number of species, and Thalassia testudinum characteristics were examined using linear and stepwise multiple regression (minimum tolerance for entry into model $=0.01$, alpha-to-enter and alpha-to-remove $=$ 0.15 ). Standard analysis of covariance (ANCOVA) was used to test for site differences in the relationship between macrofaunal density and abundance of detritus.

For each variable measured, means of the quadrats or cores for each of the 8 plots per site were used in statistical analyses $(\alpha=0.05)$. Variances in all analyses were homogeneous (Cochran's Test, $\mathrm{p} \geq 0.05$ ) unless otherwise noted. Tukey's HSD multiple comparison test was used for comparison of treatment effects. Unless otherwise noted, variation around the mean is reported as standard deviation.

\section{RESULTS}

\section{Effects of conch on macrophytes}

Wild conch densities measured in the open plots and in the surrounding area were similar at both sites (Fig. 2). Conch were always present, subjecting open plots to uninterrupted grazing pressure. At CBC, mean density ranged from 0.1 to 1.3 conch $\mathrm{m}^{-2}$ and was generally lower than in the low density conch treatments $\left(0.6\right.$ conch $\left.\mathrm{m}^{-2}\right)$. At $\mathrm{NBC}$, mean density ranged from 0.2 to 1.4 conch $\mathrm{m}^{-2}$, and values generally lay between low and high density treatments.

The most important effect of juvenile conch occurred with seagrass detritus. Treatment effects were statistically significant in August and December (Fig. 3). Mean detritus weight was highest in the 0 -conch treatment at NBC in August $\left(79 \pm 31 \mathrm{~g}\right.$ dry wt $\left.\mathrm{m}^{-2}\right)$ and at both sites in December $(192 \pm 24$ at CBC, $10 \pm 4$ at $\mathrm{NBC}$ ) (Fig. 3). Values for the 3 treatments grazed by conch were always $<5 \mathrm{~g}$ dry wt $\mathrm{m}^{-2}$ at $\mathrm{NBC}$ during these 2 sampling periods. By December, detritus in the exclosure had increased to 3.8 times that observed in the open treatment at $\mathrm{CBC}$ and by 100 times that at NBC. There was a general decline in detritus at NBC between August and December.

Conch did not have a significant effect on Thalassia testudinum shoot density (Fig. 4) or green biomass (Fig. 5), except in May at NBC when shoot count was higher in the 0-conch treatment than in the high density conch treatment. Block effects in $T$ testudinum shoot count and living biomass were significant at NBC in August (Figs. 4 \& 5). 

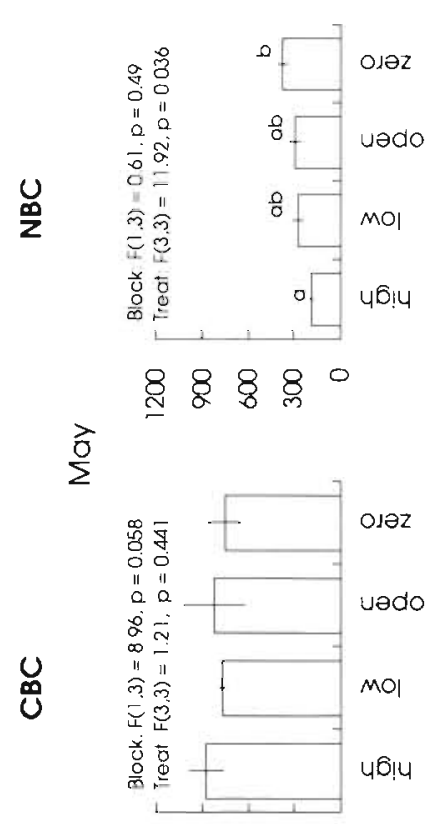

$8 \& 88^{\circ}$

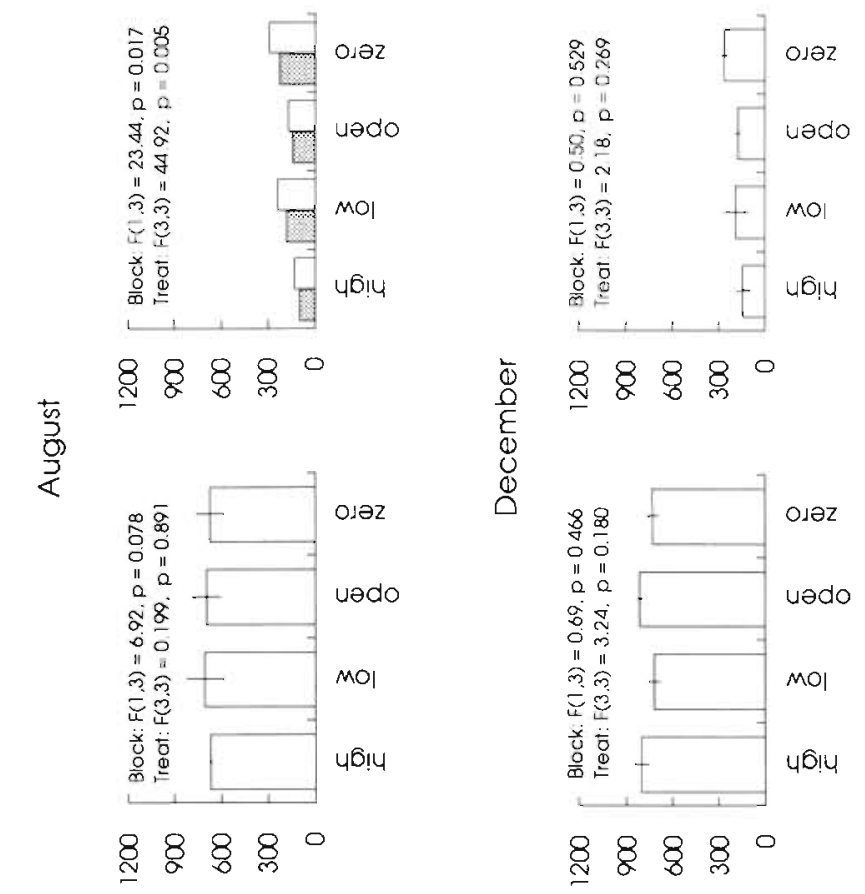

(z.w ou) K!suəa toous o!ssp/pu!
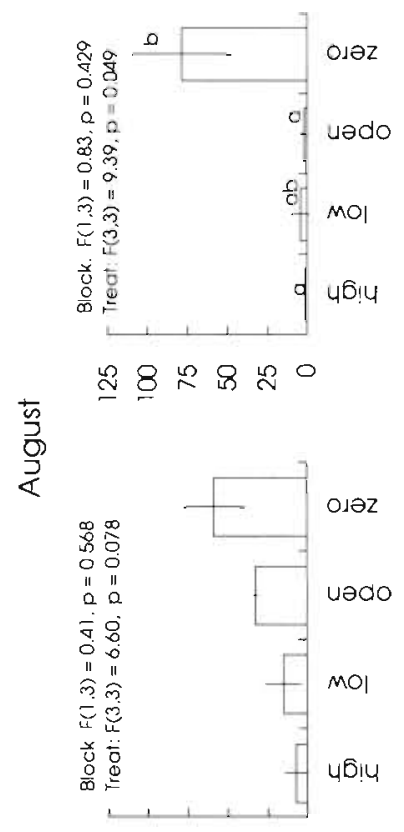

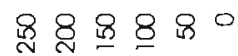

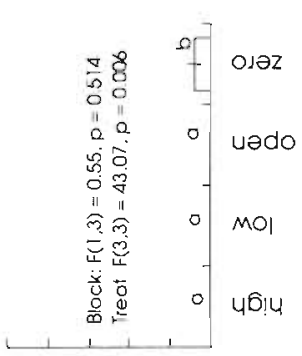

$\stackrel{2}{\simeq} \stackrel{2}{\sim} \stackrel{\circ}{\sim} 0$

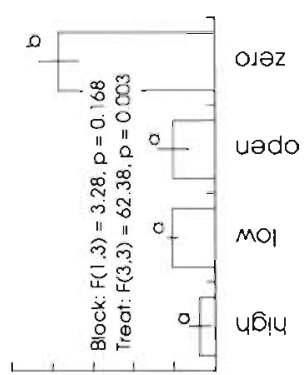

品 8

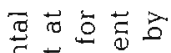

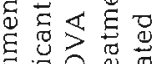

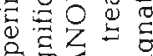

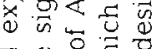

ㄷㄴㅇㅝ

$\Xi \stackrel{0}{*} \Xi$

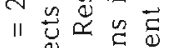

$6 \underset{0}{0}$

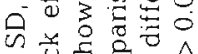

+0 i $\geq 2$

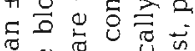

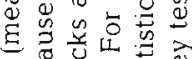

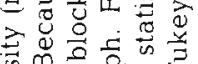

के

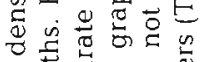

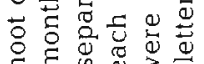

का है क ष $\frac{\pi}{\pi}$

ह่

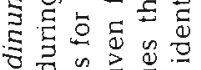

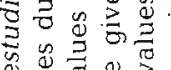

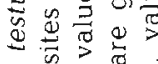

क्व

के

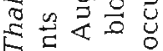

४ $\Xi$ ह

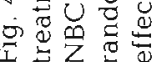

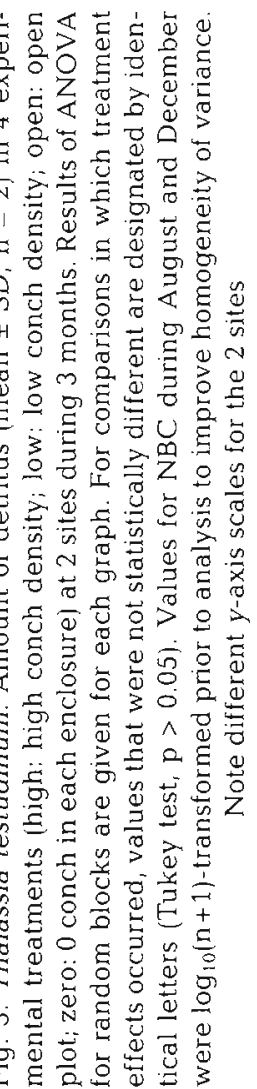

否 8

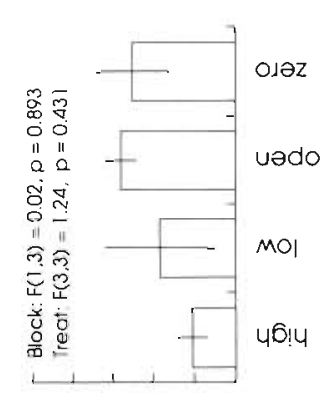

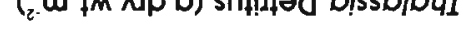


$\mathrm{CBC}$

NBC

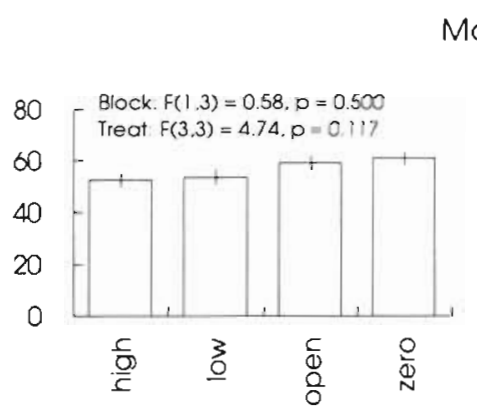

May

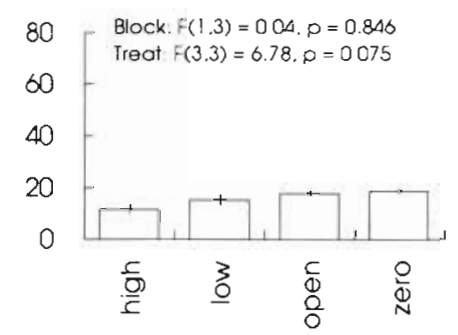

August
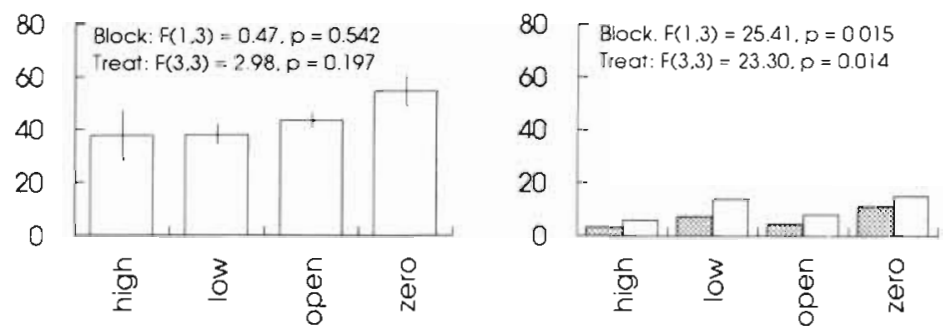

December
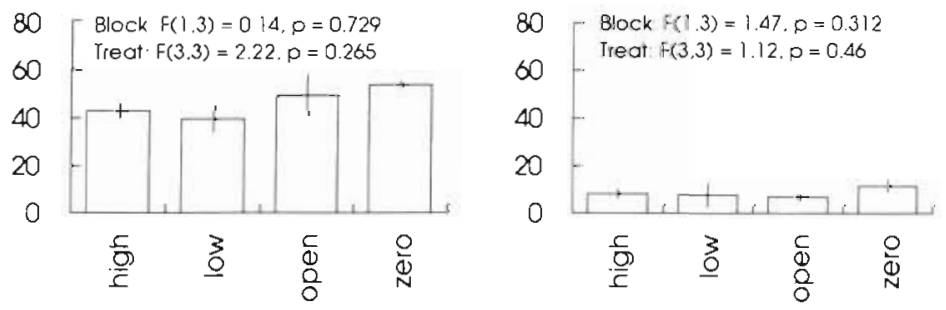

Treatment

Fig. 5. Thalassia testudinum. Biomass of living seagrass (mean $\pm S D, n=2$ ) in 4 experimental treatments at 2 sites during 3 months. Because block effects were significant at NBC in August, values for the separate blocks are shown. Results of ANOVA for random blocks are given for each graph. For comparisons in which treatment effects occurred, values that were not statistically different are designated by identical letters (Tukey test, $\mathrm{p}>0.05$ )

Overall, mean net seagrass growth (g dry wt $\mathrm{m}^{-2}$ $\left.\mathrm{d}^{-1}\right)$ was higher at $C B C(\geq 0.437)$ than NBC $(\leq 0.272)$ (Table 1), but not significantly different among the 4 treatments at either site on any of the dates examined (ANOVA, $p>0.05$ for all block and treatment effects). The highest value $(0.98 \pm 0.11)$, was observed in the open plot at CBC in September.

There were no significant block or treatment effects among epiphyte loads at either site in May, August, or December 1989 (ANOVA, p > 0.05). Mean values ranged from 3.25 to $8.30 \%$ during most of the study period but declined to $<0.90 \%$ at both sites by December (Table 1).

After the conch exclusion plots were opened to grazing in December, conch densities increased to levels higher than those observed in the plots which were always open, both at CBC $(0.90 \pm$ 0.94 vs $0.57 \pm 0.72$ conch $\mathrm{m}^{-2}$, respectively), and at $N B C(1.05 \pm 0.47$ vs 0.30 \pm 0 conch $\mathrm{m}^{-2}$ ). Differences in conch density between the treatments were not statistically significant ( $t$-tests, $p>$ 0.05 ) because of high variation, particularly at CBC. Living Thalassia testudinum and detritus remained constant between December and January in the plots which were always open, but both variables decreased significantly at $\mathrm{CBC}$ after the exclosures were removed (Fig. 6). Mean detritus concentration also decreased dramatically in the exclosure plots at NBC, but this decrease was not statistically significant, possibly due to the low number of blocks. During the observation period, values for the exclosure treatments decreased between December and January to the values measured in the plots which were always open.

\section{Intraspecific efiects}

During growth periods from March to May and May to August, conch in the low density treatment at $\mathrm{CBC}$ grew twice as fast 0.091 and $0.149 \mathrm{~mm} \mathrm{~d}^{-1}$. respectively) as in the high density plots (0.039 and $0.065 \mathrm{~mm} \mathrm{~d}^{-1}$ ) (Fig. 7). By the end of the third growth period (August to December) all of the original conch were dead or missing in the high density treatment of 1 block; most mortality was related to predation. Although the differences were not significant at NBC, mean growth rates in the low density conch treatment were always higher than in the high density treatment.

\section{Effects of conch on macrofauna}

The mean density of macrofauna (all taxa) was always higher in the conch exclusion plots than any other treatment at both field sites, and a block effect occurred only at NBC in August (Fig. 8). The treatment 
Table 1 Thalassia testudinum. Net productivity (g dry wt $\mathrm{m}^{-2}$ $d^{-1}$ ) and epiphyte loads observed at 2 sites in 1989. Epiphyte loads are expressed as percentages ( $g$ dry epiphytes $g^{-1} d r y^{\prime}$ $T$. testudinum $\times 100)$. Values are mean $\pm \mathrm{SD}(\mathrm{n}=4)$

\begin{tabular}{lcc|}
\hline & CBC & NBC \\
\hline $\begin{array}{l}\text { Productivity } \\
\text { March }\end{array}$ & $0.437 \pm 0.025$ & $0.244 \pm 0.025$ \\
May & $0.477 \pm 0.045$ & $0.272 \pm 0.025$ \\
September & $0.881 \pm 0.115$ & $0.262 \pm 0.042$ \\
Epiphyte load & & \\
March & $6.08 \pm 1.02$ & $7.64 \pm 1.92$ \\
May & $7.08 \pm 1.33$ & $8.30 \pm 1.86$ \\
August & $3.25 \pm 0.61$ & $5.19 \pm 1.27$ \\
December & $0.61 \pm 0.07$ & $0.87 \pm 0.25$ \\
\hline
\end{tabular}

effect was always significant $(p<0.03)$ at $N B C$, with greatest differences between exclusion plots and all other treatments at the end of the experiment. In
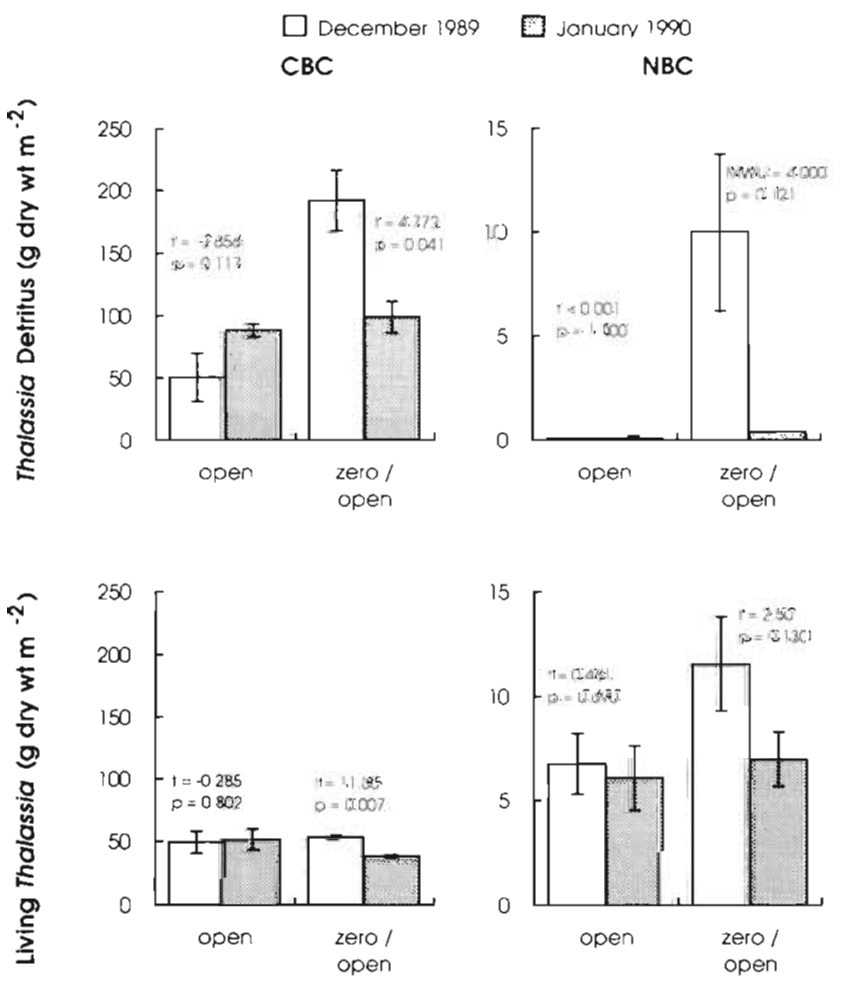

Treatment

Fig. 6. Thalassia testudinum. Biomass of living seagrass and detritus (mean $\pm \mathrm{SD}, \mathrm{n}=2$ ) for 2 treatments at 2 sites during 2 months. Wild conch had access to the open treatment prior to December and no access to the zero/open treatment until December, when the exclosure screens were removed. Results are from Student's $t$-tests except at NBC in the zero/open treatment. In this case a Mann-Whitney $U$-test was performed because variances were heterogeneous despite $\log _{10}(n+1)$-transformation

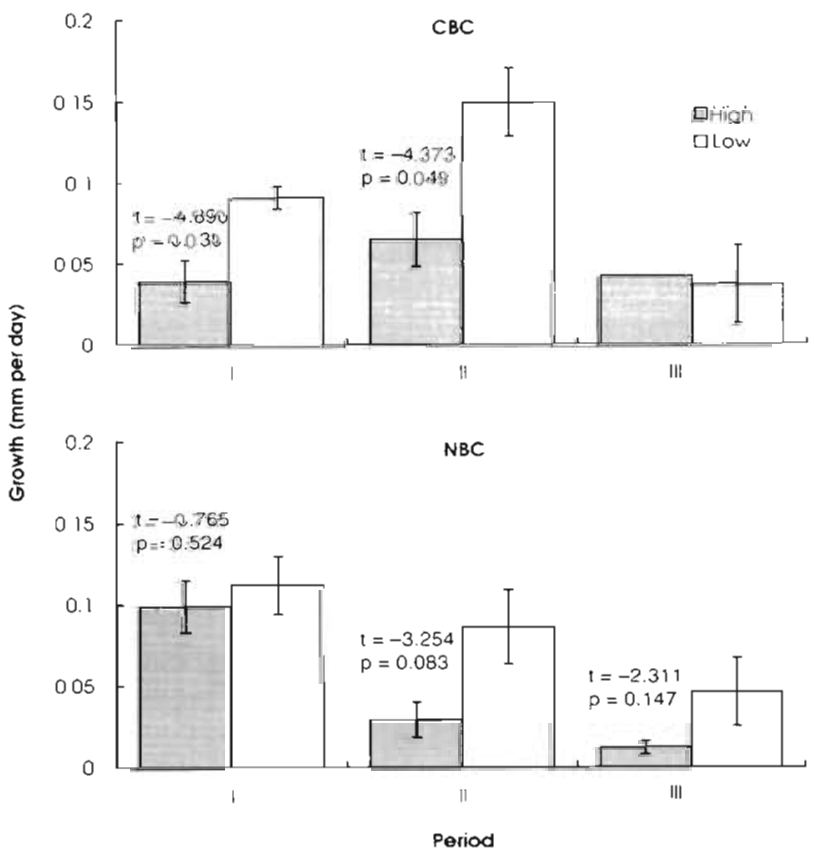

Fig. 7 . Strombus gigas. Conch growth rates (mean $\pm \mathrm{SD}, \mathrm{n}=2$ ) in high $\left(1.2\right.$ conch $\left.\mathrm{m}^{-2}\right)$ and low $\left(0.6\right.$ conch $\left.\mathrm{m}^{-2}\right)$ density treatments at 2 sites in 1989 ( $\mathrm{I}=3$ April to 19 May, II = 19 May to 21 August, III = 21 August to 15 December). Results from Student's $t$-test are given for all pairs except $C B C$, period IIl, when all original conch in the high density treatment of one block were dead or missing by the end of the experiment

December, the ungrazed plots had an average of 6610 macrofauna $\mathrm{m}^{-2}$; all other plots had less than 2000 macrofauna $\mathrm{m}^{-2}$ (Fig. 8). In the open treatments, mean densities ranged from 1447 to 2473 macrofauna $\mathrm{m}^{-2}$ at $\mathrm{NBC}$ and from 1480 to 3046 macrofauna $\mathrm{m}^{-2}$ at CBC. Nevertheless, treatment differences were not statistically significant $(\mathrm{p}>0.10)$ at CBC.

Linear regressions were run for macrofauna density using Thalassia testudinum characteristics (shoot density, living biomass, and detritus) as independent variables (Table 2). At NBC the relationship was positive and significant for all 3 variables at the end of the experiment in December and for shoot density and living $T$. testudinum in May. At CBC the relationship was positive and significant for detritus and living $T$. testudinum at all 3 sampling times, except for living $T$. testudinum in December. Highest correlations occurred between macrofaunal density and detritus at the end of the experiment (Fig. 9). In 2 of the 4 cases in which the relationship between macrofauna and detritus was highly significant, the relationship was improved by addition of a second variable in stepwise multiple regression. At CBC in May, detritus and shoot density together accounted for $85 \%$ of the variation, and at NBC in December, detri- 
CBC

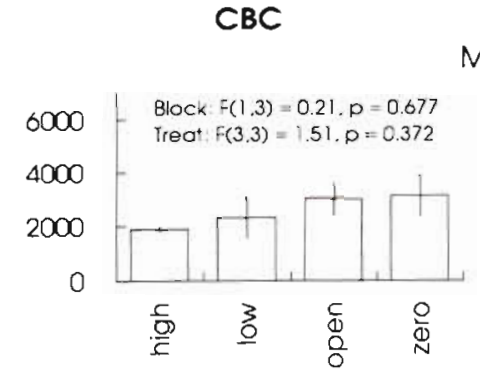

NBC

May

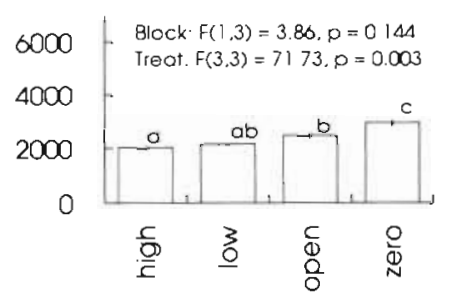

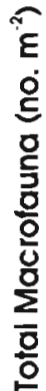

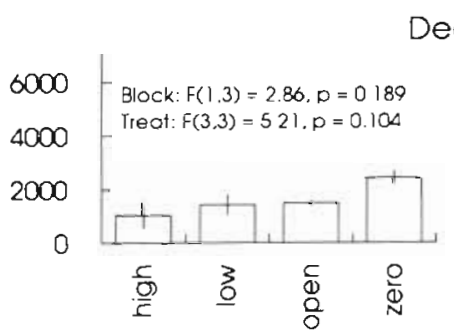

August

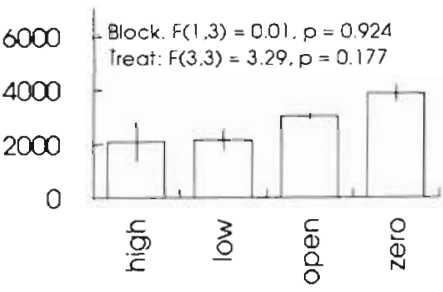

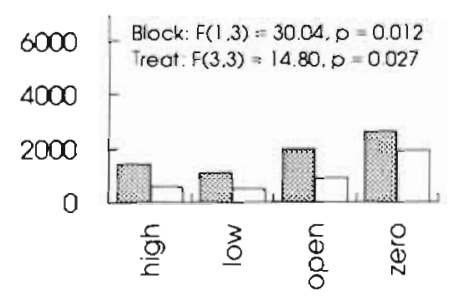

December

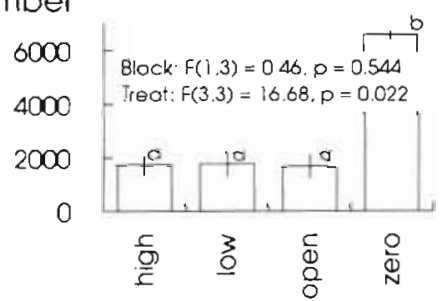

Treatment

Fig 8. Total number of macrofauna (mean $\pm \mathrm{SD}, \mathrm{n}=2$ ) found in 4 experimental treatments at 2 sites during 3 months. Because block effects were significant at NBC in August, values for the separate blocks are shown. Results of ANOVA for random blocks are given for each graph. For comparisons in which treatment effects occurred, values that were not statistically different are designated by identical letters (Tukey test, $\mathrm{p}>0.05$ )

tus and living $T$. testudinum biomass together accounted for $97 \%$ of the variation (Table 2).

The relationship between detritus and macrofaunal data was not consistent between the 2 study sites. ANCOVA showed a higher number of macrofauna per unit detritus at NBC than at CBC in May $\left(F_{(1,13)}=9.538, \mathrm{p}=0.009\right)$, but the reverse was true in August $\left(F_{\{1,13\}}=9.17\right.$, $\mathrm{p}=0.01$ ). ANCOVA was not run for December data because slopes for the 2 sites were not equivalent $\left(F_{(1,12)}=98.45, \mathrm{p}\right.$ $<0.001$ ).

A total of 211 different species was encountered during this study. December data showed no individual species to be particularly dominant numerically, and relative compositional differences among the treatments were subtle (Table 3). Absolute numerical differences were more significant, and numbers of individual species collected were generally higher in the 0 -conch treatment than in the high density treatment. There were a few exceptions: the amphipod Lembos unifasciatus was more abundant in the high density conch enclosures than in the exclusion plots at $C B C$; the amphipod Acuminodeutopus naglei, apseudid sp. no. 2 (tanaid), and Cumacea sp. no. 3 had relatively similar counts among the treatments.

At NBC the amphipod Ceradocus shoemakeri was never observed in the high

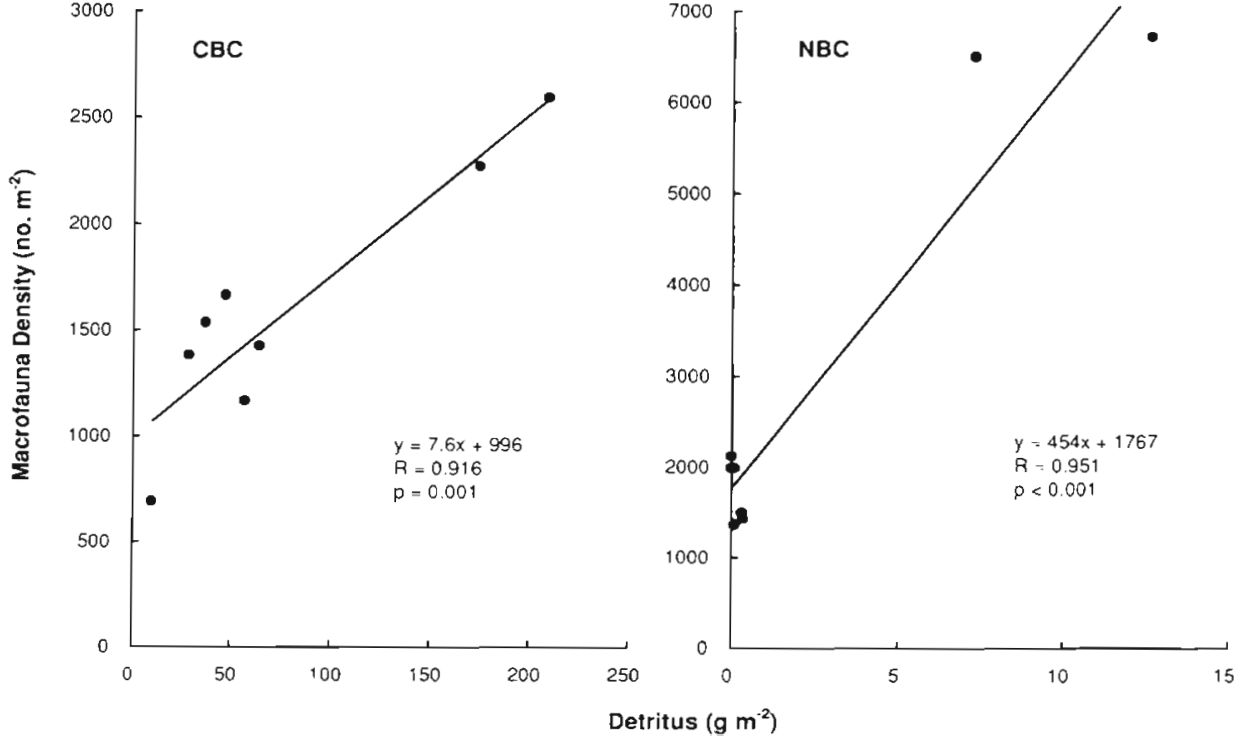

Fig. 9. Relationships between macrofauna density in the experimental plots and concentration of Thalassia testudinum detritus at the 2 study sites. Note differences in the $x$-and $y$-axes 
Table 2. Thalassia testudinum. Correlation coefficients (r) for the linear relationship between the dependent variable macrofauna density (total no. $\mathrm{m}^{-2}$ ) and 3 independent variables: $T$. testudinum shoot density (no. $\mathrm{m}^{-2}$ ), living $T$. testudinum biomass (g dry wt $\mathrm{m}^{-2}$ ), and $T$. testudinum detritus $\left(\mathrm{g}\right.$ dry $\mathrm{wt} \mathrm{m}^{-2}$ ) during 3 months in 1989 . The order in which stepwise multiple regression determined significant contribution to the model is given followed by the percentage of variation explained (Var.). F and p values are for the multiple regression for each site and date

\begin{tabular}{|c|c|c|c|c|c|c|c|c|c|}
\hline & \multicolumn{3}{|c|}{$\mathrm{r}$} & \multicolumn{6}{|c|}{ Results of multiple regression } \\
\hline & \multirow[t]{2}{*}{ May } & \multirow[t]{2}{*}{ Aug } & \multirow[t]{2}{*}{ Dec } & \multicolumn{2}{|c|}{ May } & \multicolumn{2}{|c|}{ Aug } & \multicolumn{2}{|c|}{ Dec } \\
\hline & & & & Order & Var & Order & Var. & Order & Var. \\
\hline \multicolumn{10}{|l|}{$\mathrm{CBC}$} \\
\hline Living $T$. testudinum & $0.779^{\circ}$ & $0.898^{\cdots}$ & 0.547 & & & $1 \mathrm{st}$ & $81 \%$ & & \\
\hline T. testudinum shoot density & -0.291 & 0.174 & -0.342 & 2nd & $11 \%$ & & & & \\
\hline \multirow[t]{2}{*}{ T. testudinum detritus } & $0.858^{\cdots}$ & $0.865 \cdots$ & $0.916^{*}$ & $1 \mathrm{st}$ & $74 \%$ & & & 1st & $84 \%$ \\
\hline & & & & \multicolumn{2}{|c|}{$\begin{array}{c}F_{(2,5)}=14.12 \\
p=0.009\end{array}$} & \multicolumn{2}{|c|}{$\begin{array}{c}F_{(1.6)}=24.97 \\
p=0.002\end{array}$} & \multicolumn{2}{|c|}{$\begin{array}{c}F_{(1,6)}=31.10 \\
p=0.001\end{array}$} \\
\hline \multicolumn{10}{|l|}{ NBC } \\
\hline Living $T$. testudinum & $0.832 \cdots$ & 0.096 & $0.701^{\circ}$ & & & & & 2nd & $7 \%$ \\
\hline T. testudinum shoot density & $0.879 \cdot \cdot$ & 0.258 & $0.803^{\circ}$ & $1 \mathrm{st}$ & $77 \%$ & & & & \\
\hline \multirow[t]{2}{*}{ T. testudinum detritus } & 0.456 & 0.629 & $0.951^{\cdots}$ & & & $1 s t$ & $40 \%$ & $1 \mathrm{st}$ & $90 \%$ \\
\hline & & & & \multicolumn{2}{|c|}{$\begin{array}{c}F_{(1,6)}=20.31 \\
p=0.004\end{array}$} & \multicolumn{2}{|c|}{$\begin{array}{c}F_{(16)}=3.93 \\
p=0.095\end{array}$} & \multicolumn{2}{|c|}{$\begin{array}{c}F_{(2,5)}=84.78 \\
p<0.001\end{array}$} \\
\hline
\end{tabular}

density and open treatments, but 58 were collected from the 0 -conch treatment, representing $12 \%$ of the total (Table 3 ). This species constructs tubes from bits of detritus, which was significantly more abundant in the 0 -conch treatment (Fig. 3). Also at NBC the following species were at least 6 times more abundant in the 0 conch treatment than in the high density treatment: ostracods $(6 \times)$, the isopod Carpius spp. $(7 \times)$, and the amphipod Batea catharinensis $(11 x)$.

At CBC, there were nearly 5 times as many of the tanaid Apseudes espinosus sp. no. 1 in the 0 -conch treatment $(n=49)$ as in high conch density, and this was the most abundant species in 3 of the 4 treatments (Table 3). The amphipod Microdeutopus myersi was only found in the open and 0 -conch treatments.

Twenty-two more species were encountered in the 0 -conch treatment than in the high density treatment at $\mathrm{NBC}$, and 13 more were encountered at CBC (Table 3). Also, the 0 -conch treatment showed higher totals of individual macrofauna at both sites. Differences were $2.3 \times$ at CBC and $3.8 \times$ at NBC (Table 3). ANOVA for the total number of macrofauna species found per core sample showed a significant treatment effect at NBC in December (Fig. 10). There was a significantly higher number of species in the conch exclusion

\section{CBC}

NBC

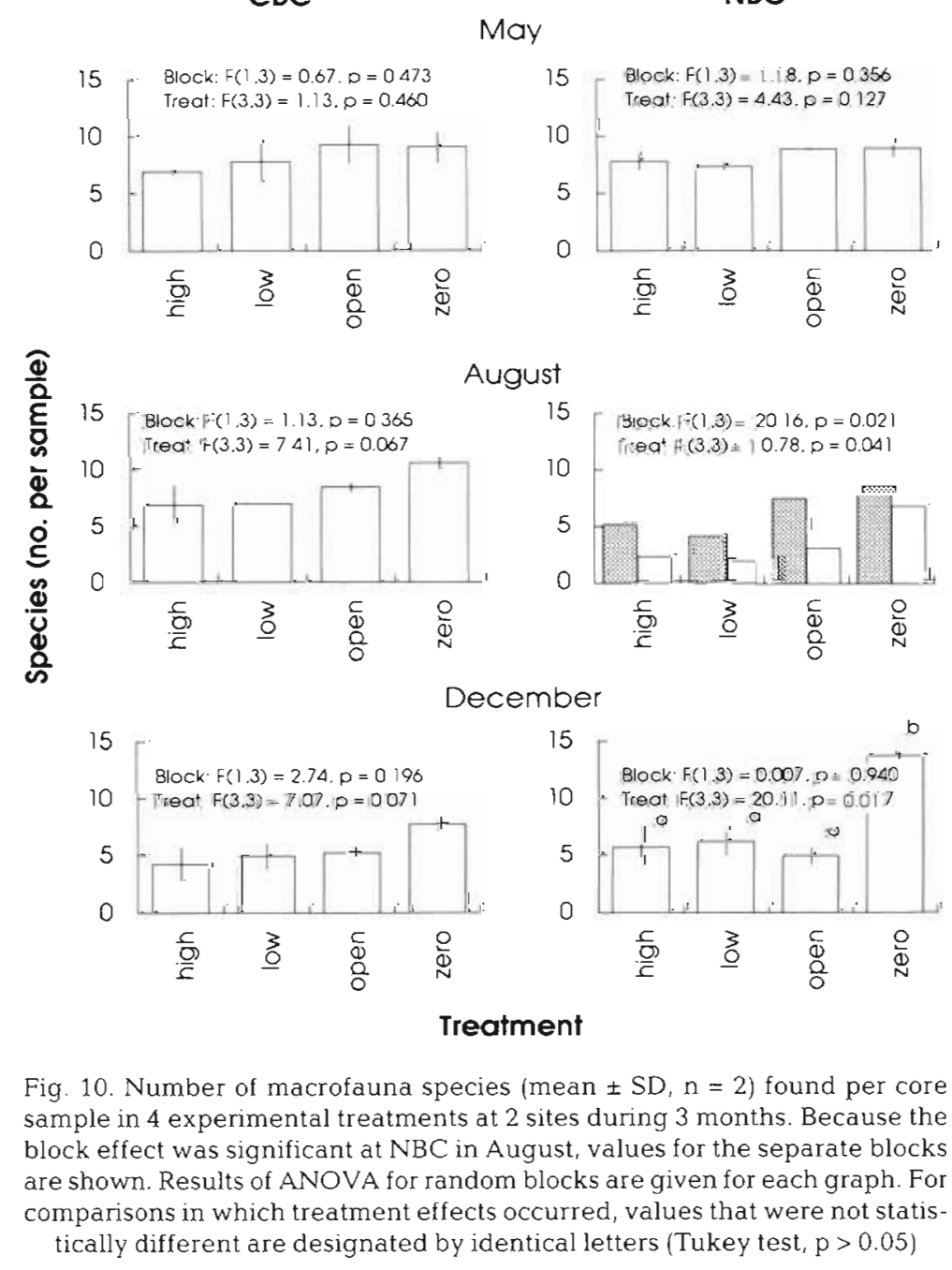


Table 3. Macrofaunal composition for 4 treatments at CBC and NBC in December 1989. Included species are those that represent $>2 \%$ of the total macrofauna found at each site. The first value for each treatment is the total number of that species found in 20 cores $\left(10\right.$ cores block $\left.{ }^{-1}\right)$ followed by its percentage of the total included species. $N$ is the total number of all individuals encountered, and $S$ is the total number of species in the 20 cores of each treatment. Totals included the taxa representing $<2 \%$

\begin{tabular}{|c|c|c|c|c|c|}
\hline \multirow[t]{2}{*}{ Species } & \multirow{2}{*}{$\begin{array}{c}\text { Taxonomic } \\
\text { group }\end{array}$} & \multicolumn{4}{|c|}{ Treatment } \\
\hline & & High & Low & Open & Zero \\
\hline \multicolumn{6}{|l|}{$\mathrm{CBC}$} \\
\hline Apseudes espinosus sp. no. 1 & Tanaid & $10(16)$ & $16(18)$ & $22(24)$ & $49(32)$ \\
\hline Apseudes propinquus & Tanaid & $9(15)$ & $20(22)$ & $11(12)$ & $12(8)$ \\
\hline Leptochelia dubia & Tanaid & $8(13)$ & $5(6)$ & $3(3)$ & $11(7)$ \\
\hline Leptochelia sp. no. 1 & Tanaid & $4(7)$ & $3(3)$ & $10(11)$ & $7(5)$ \\
\hline Xenanthura brevitelson & Isopod & $5(8)$ & $3(3)$ & $6(6)$ & $6(4)$ \\
\hline Acuminodeutopus naglei & Amphipod & $5(8)$ & $5(6)$ & $5(5)$ & $5(3)$ \\
\hline Leptochelia forresti & Tanaid & $1(2)$ & $3(3)$ & $7(8)$ & $8(5)$ \\
\hline Cumacea sp. no. 2 & Cumacean & $2(3)$ & $7(8)$ & $0(0)$ & $9(6)$ \\
\hline Protohadzia schoenerae & Amphipod & $1(2)$ & $4(4)$ & $0(0)$ & $13(8)$ \\
\hline Cumella sp. & Cumacean & $1(2)$ & $1(1)$ & $5(5)$ & $10(6)$ \\
\hline Ostracoda & Ostracod & $3(5)$ & $2(2)$ & $5(5)$ & $6(4)$ \\
\hline Leptochelia spp. & Tanaid & $3(5)$ & $4(4)$ & $6(6)$ & $3(2)$ \\
\hline Apseudes espinosus sp. no. 2 & Tanaid & $1(2)$ & $6(7)$ & $4(4)$ & $4(3)$ \\
\hline Microdeutopus myersi & Amphipod & $0(0)$ & $0(0)$ & $5(5)$ & $9(6)$ \\
\hline Apseudid sp. no. 1 & Tanaid & $2(3)$ & $8(9)$ & $3(3)$ & $0(0)$ \\
\hline Lembos unifasciatus & Amphipod & $6(10)$ & $2(2)$ & $1(1)$ & $3(2)$ \\
\hline$N$ & & 96 & 131 & 137 & 225 \\
\hline$S$ & & 41 & 46 & 39 & 54 \\
\hline \multicolumn{6}{|l|}{ NBC } \\
\hline Ostracoda & Ostracod & $22(24)$ & $21(19)$ & 22 (25) & $146(30)$ \\
\hline Carpius spp. & Isopod & $14(15\}$ & $13(12)$ & $25(28)$ & $101(20)$ \\
\hline Batea catharinensis & Amphipod & $4(4)$ & $10(9)$ & $7(8)$ & $44(9)$ \\
\hline Ceradocus shoemakeri & Amphipod & $0(0)$ & $2(2)$ & $0(0)$ & $58(12)$ \\
\hline Cumella sp. & Cumacean & $10(11)$ & $9(8)$ & $4(4)$ & $20(4)$ \\
\hline Cumacea sp. no. 1 & Cumacean & $5(5)$ & $8(7)$ & $3(3)$ & $24(5)$ \\
\hline Apseudes espinosus sp. no. 1 & Tanaid & $4(4)$ & $5(5)$ & $4(4)$ & $22(4)$ \\
\hline Leptochelia dubia & Tanaid & $1(1)$ & $4(4)$ & $5(6)$ & $24(5)$ \\
\hline Xenanthura brevitelson & Isopod & $8(9)$ & $9(8)$ & $1(1)$ & $15(3)$ \\
\hline Lightiella cf. incisa & Cephalocarid & $5(5)$ & $6(6)$ & $4(4)$ & $15(3)$ \\
\hline Apseudid sp. no. 2 & Tanaid & $6(7)$ & $10(9)$ & $6(7)$ & $6(1)$ \\
\hline Listriella barnardi & Amphipod & $6(7)$ & $9(8)$ & $0(0)$ & $11(2)$ \\
\hline Cumacea sp. no. 3 & Cumacean & $7(8)$ & $3(3)$ & $8(9)$ & $7(1)$ \\
\hline$N$ & & 161 & 164 & 155 & 612 \\
\hline$S$ & & 43 & 45 & 33 & 65 \\
\hline
\end{tabular}

Table 4. Correlation coefficients ( $r$ ) for the linear relationship between number of macrofauna (independent variable) and number of species (dependent variable) per plot ( $\mathrm{n}=8$ at each of 2 sites). Variables were $\log _{10}$-transformed prior to analysis. Data were collected during 3 months in 1989

\begin{tabular}{|lcr|}
\hline & $\mathrm{r}$ & $\mathrm{p}$ \\
\hline $\mathrm{CBC}$ & & \\
May & 0.643 & 0.085 \\
August & 0.796 & 0.018 \\
December & 0.938 & 0.001 \\
NBC & & \\
May & 0.510 & 0.197 \\
August & 0.967 & $<0.001$ \\
December & 0.916 & 0.001 \\
\hline
\end{tabular}

plots (mean $=14$ species sample ${ }^{-1}$ ) than in any other treatment ( $\leq 6$ species). Except for a block effect at NBC in August, no other significant effects were observed at either site during the 3 months. The minimum mean number of species was 3 per sample, observed in the low density conch treatment at NBC in August.

Numbers of species collected are often related to sampling effort and to numbers of individuals collected, and our results proved no exception. The total number of different species from all 10 core samples taken in each of the 8 plots at both sites was correlated with total number of macrofauna in May, August, and December (Table 4). The relationship was positive and significant, except in May. 


\section{DISCUSSION}

As an herbivore and detritivore, Strombus gigas plays an important role in seagrass communities. Effects are particularly obvious when conch juveniles form very high density mass migrations containing $>250$ conch $\mathrm{m}^{-2}$ and consume significant quantities of the macroalgae, seagrass detritus, epiphytes, and sediment organics in their paths (Stoner 1989a, Stoner \& Lally 1994). This study shows that even much lower densities of conch $\left(0.6\right.$ and $\left.1.2 \mathrm{~m}^{-2}\right)$ typically found in nursery grounds can have a direct effect on the macrophyte community, thereby having an important indirect effect on macrofauna that shelter in it. By consuming significant quantities of Thalassia testudinum detritus, conch can affect macrofauna community structure by competing for common food sources or by reduction of protective structure, making certain species more vulnerable to predation. However, conch had no discernible effect on epiphytes nor on any other $T$. testudinum characteristic examined (shoot density, living biomass, or growth).

Queen conch had little effect on living Thalassia testudinum because they rarely consume live seagrass (Randall 1964, Stoner \& Waite 1991) and because the epiphyte loads on seagrass blades observed in this study were low and uninfluenced by conch grazing. Epiphyte loads observed near Lee Stocking Island were always $<9 \%$, decreasing to $<1 \%$ in the winter sampling. Effects of epiphytes on seagrass growth have been reported for sites that are more eutrophic than the Bahamian banks and where epiphyte biomass or productivity are higher (Bulthuis \& Woelkerling 1983, van Montfrans et al. 1984).

While conch had no apparent effect on living Thalassia testudinum or epiphytes, they significantly reduced T. testudinum detritus, which is an important food item (Stoner \& Waite 1991). In August and December plots protected from conch grazing had more detritus than any of the 3 treatments subjected to conch grazing, and detritus abundance was inversely related to manipulated conch density. The fact that the open treatment, grazed by free-ranging conch, had less detritus than the 0 -conch treatment suggests that even relatively low densities of juvenile conch had a significant grazing effect. When exclusion cages were opened in December conch rapidly entered the plots, undoubtedly to exploit the detrital food that had accumulated over the previous 9 mo. Detrital weights decreased quickly thereafter.

Grazing was sufficiently intense in the high density treatment to become limiting to conch growth at $C B C$, where growth during the first 2 periods was less than half that observed at low density. Stoner (1989b) measured comparable growth rates (>0.1 $\mathrm{mm} \mathrm{d}^{-1}$ ) among free-ranging animals at $\mathrm{CBC}$ and observed density- dependent effects on growth when densities were manipulated to $>2.0$ conch $\mathrm{m}^{-2}$. Results from this experiment show that, under certain circumstances, effects occur at even lower density levels. Despite the comparatively low detritus levels at NBC, initial growth rates were high, and differences, though not significant, were evident only during the second and third periods. Mats of cyanobacteria and diatoms were present in the shallow water at NBC and probably provided an important food source for juvenile conch. Despite low detritus abundance at NBC, compared to $C B C$, macrofauna densities per unit detritus were higher at NBC than $C B C$ in May, and the highest values were observed at $\mathrm{NBC}$ in December. Effects in the enclosures were most likely compounded over time.

Macrofauna may compete for shelter (Heck \& Orth 1980), and many studies have shown a positive correlation between seagrass biomass and macrofauna abundance (see review by Orth et al. 1984, Heck \& Crowder 1991). Despite the large number of investigations which have examined the effects of herbivory on marine plants (Dean et al. 1984, Hay 1984, Thayer et al. 1984, Carpenter 1988) and the effects of habitat complexity on macrofauna distribution (Heck \& Wetstone 1977, Heck \& Orth 1980, Bell \& Westoby 1986, Hicks 1986, Heck \& Crowder 1991), analyses of the indirect effects of herbivory on macrofauna are uncommon, and manipulations of vegetation structures in seagrass meadows other than the live seagrasses themselves have rarely been made (Stoner \& Lewis 1985). This study shows significant consequences when conch remove detritus, an important component of the overall vegetative structure that provides food and shelter for benthic invertebrates (Kikuchi 1980, Heck \& Thoman 1981, Stoner 1989b). Although a few species increased or remained unaffected as a result of increased detritivory, large increases in most epibenthic macrofauna (e.g. amphipods Ceradocus shoemakeri and Batea catherinensis and ostracods) and tubebuilding tanaidaceans (e.g. Apseudes espinosus and Leptochelia dubia) indicate that the increased shelter provided by detritus had a strong positive effect on macrofaunal abundance in the exclosures.

Large aggregations of juvenile queen conch move continually over suitable nursery habitat in seagrass meadows of the Bahamas (Stoner \& Ray 1993, Ray \& Stoner 1994). Because of the high biomass in these aggregations (typically 30 to $100 \mathrm{~g}$ wet tissue wt $\mathrm{m}^{-2}$, Stoner \& Waite 1990) and their high grazing capacity, it is likely that queen conch keep the macrofloral community in constant flux. As a result of their grazing habits and the direct correlation between detritus and the density of epibenthic macrofauna, juvenile queen conch play a major role in shaping community structure in the seagrass nursery grounds. 
Acknowledgements. This research was supported by grants from the National Undersea Research Program, NOAA, U.S. Department of Commerce and the Shearwater Foundation, New York. We are grateful to P. Bergman, K. Schwarte, V. Sandt, and E. Wishinski for their help in the field and lab. $B$. Yoshioka conducted most of the macrofauna taxonomic analysis. Helpful criticism of the manuscript was provided by M. Davis, W. G. Nelson, and 2 anonymous reviewers.

\section{LITERATURE CITED}

Ansari ZA, Rivonker CU, Ramani P, Parulekar AH (1991) Seagrass habitat complexity and macroinvertebrate abundance in Lakshadweep coral reef lagoons, Arabian Sea. Coral Reefs 10:127-131

Bell JD, Westoby $M$ (1986) Abundance of macrofauna in dense seagrass is due to habitat preference, not predation. Oecologia 68:205-209

Bulthuis DA, Woelkerling WJ (1983) Biomass accumulation and shading effects of epiphytes on leaves of the seagrass, Heterozostera tasmanica, in Victoria, Australia. Aquat Bot $16: 137-148$

Carpenter RC (1986) Partitioning herbivory and its effects on coral reef algal communities. Ecol Monogr 56:345-363

Carpenter RC (1988) Mass mortality of a Caribbean sea urchin: immediate effects on community metabolism and other herbivores. Ecology 85:511-514

Carpenter RC (1990) Mass mortality of Diadema antillarum. II. Effects on population densities and grazing intensity of parrotfishes and surgeonfishes. Mar Biol 104:79-86

Connell JH (1975) Some mechanisms producing structure in natural communities: a model and evidence from field experiments. In: Cody ML, Diamond JM (eds) Ecology and evolution of communities. Belknap Press of Harvard University, Cambridge, $\mathrm{p} 460-490$

Cooper WE, Crowder LE (1979) Patterns of predation in simple and complex environments. In: Shoud RH, Clopper $\mathrm{H}$ (eds) Predator prey systems in fisheries management. Sport Fishing Institute, Washington, DC, p 257-267

Dean TA, Schroeter SC, Dixon JD (1984) Effects of grazing by two species of sea urchins (Strongylocentrotus franciscanus and Lytechinus anamesus) on recruitment and survival of two species of kelp (Macrocystis pyrifera and Pterygophora californica). Mar Biol 78:301-313

Gilinsky E (1984) The role of fish predation and spatial heterogeneity in determining benthic community structure. Ecology 65:455-468

Hay ME (1984) Patterns of fish and urchin grazing on Caribbean coral reefs: are previous results typical? Ecology 65:446-454

Hay ME (1991) Fish-seaweed interactions on coral reefs effects of herbivorous fishes and adaptations of their prey. In: Sale PF (ed) The ecology of fishes on coral reefs. Academic Press, San Diego, p 96-119

Heck KL Jr, Crowder LB (1991) Habitat structure and predator-prey interactions in vegetated aquatic systems. In: Bell SS, MCCoy ED, Mushinsky HR (eds) Habitat structure: the physical arrangement of objects in space. Chapman and Hall, New York, p 281-299

Heck KL Jr, Orth RJ (1980) Seagrass habitats: the roles of habitat complexity, competition and predation in structuring associated fish and motile macroinvertebrate assemblages. In: Kennedy VS (ed) Estuarine perspectives. Academic Press, New York, p 449-464

Heck KL Jr, Thoman TA (1981) Experiments on predator-prey interactions in vegetated aquatic habitats. $J$ exp mar Biol
Ecol 53:125-134

Heck KL Jr, Wetstone GS (1977) Habitat complexity and invertebrate species richness and abundance in tropical seagrass meadows. J Biogeogr 4:135-142

Heck KL Jr, Wilson KA (1987) Predation rates on decapod crustaceans in latitudinally separated seagrass communities: a study of spatial and temporal variation using tethering techniques. J exp mar Biol Ecol 107:87-100

Hicks GRF (1986) Distribution and behaviour of meiofaunal copepods inside and outside seagrass beds. Mar Ecol Prog Ser 31:159-170

Homziak J, Fonseca MS, Kenworthy WJ (1982) Macrobenthic community structure in a transplanted eelgrass (Zostera marinal meadow. Mar Ecol Prog Ser 9:211-221

Horn MH (1989) Biology of marine herbivorous fishes. Oceanogr mar Biol A Rev 27:167-272

Howard RK, Short FT (1986) Seagrass growth and survivorship under the influence of epiphyte grazers. Aquat Bot $24: 287-302$

Hughes TP (1994) Catastrophes, phase shifts, and large-scale degradation of a Caribbean coral reef. Science 265: $1547-1551$

Hurlbert HS (1984) Pseudoreplication and the design of ecological field experiments. Ecol Monogr 54:187-211

Kikuchi I (1980) Faunal relationships in temperate seagrass beds. In: Phillips RC, McRoy CP (eds) Handbook of seagrass biology, an ecosystem perspective. Garland STPM Press, New York, p 153-172

Lawrence JM (1975) On the relationships between marine plants and sea urchins. Oceanogr mar Biol A Rev 13: $213-286$

Liddell WD, Ohlhorst SL (1986) Changes in benthic community composition following the mass mortality of Diadema at Jamaica. J exp mar Biol Ecol 95:271-278

Lubchenco JL. Gaines SD (1981) A unified approach to marine plant-herbivore interactions. I. Populations and communities. A Rev Ecol Syst 12:405-437

Ogden JC, Brown RA, Salesky N (1973) Grazing by the echinoid Diadema antillarum Phipippi: formation of halos around West Indian Patch Reefs. Science 182:715-716

Ojeda FP, Dearborn JH (1991) Feeding ecology of benthic mobile predators: experimental analyses of their influence in rocky subtidal communities of the Gulf of Maine. J exp mar Biol Ecol 149:13-44

Orth RJ, Heck KL Jr, van Montfrans J (1984) Faunal communities in seagrass beds: a review of the influence of plant structure and prey characteristics on predator prey relationships. Estuaries 7:339-350

Paine RT, Vadas RL (1969) The effects of grazing by sea urchins Strongylocentrotus spp. on benthic algal populations. Limnol Oceanogr 14:710-719

Randall JE (1964) Contributions to the biology of the queen conch, Strombus gigas. Bull mar Sci Gulf Caribb 14: $246-295$

Randall JE (1965) Grazing effect on seagrasses by herbivorous reef fishes in the West Indies. Ecology 46:255-260

Ray M. Stoner AW (1994) Experimental analysis of growth and survivorship in a marine gastropod aggregation: balancing growth with safety in numbers. Mar Ecol Prog Ser $105: 47-59$

Sandt VJ, Stoner AW (1993) Ontogenetic shift in habitat by early juvenile queen conch, Strombus gigas: patterns and potential mechanisms. Fish Bull US 91:516-525

Stoner AW (1980) The role of seagrass biomass in the organization of benthic macrofaunal assemblages. Bull mar Sci $30: 537-551$

Stoner AW (1989a) Winter mass migration of juvenile queen 
conch Strombus gigas and their influence on the benthic environment. Mar Ecol Prog Ser 56:99-104

Stoner AW (1989b) Density-dependent growth and grazing effects of juvenile queen conch Strombus gigas $L$. in a tropical seagrass meadow. J exp mar Biol Ecol 130:119-133

Stoner AW. Hanisak MD, Smith NP, Armstrong RA (1994) Large-scale distribution of queen conch nursery habitats: implications for stock enhancement. In: Appeldoorn RS. Rodriguez B (eds) Queen conch biology, fisheries, and mariculture. Fundación Cientifica Los Roques, Caracas, p 169-189

Stoner AW, Lally J (1994) High-density aggregation in queen conch Strombus gigas: formation, patterns, and ecological significance. Mar Ecol Prog Ser 106:73-84

Stoner AW, Lewis FG III (1985) The influence of quantitative and qualitative aspects of habitat complexity in tropical sea-grass meadows. J exp mar Biol Ecol 94:19-40

Stoner AW, Pitts PA, Armstrong RA (1995) The interaction of physical and biological factors in the large-scale distribution of juvenile queen conch in seagrass meadows. Bull mar Sci (in press)

Stoner AW, Ray M (1993) Aggregation dynamics in juvenile queen conch (Strombus gigas): population structure, mortality, growth, and migration. Mar Biol 116:571-582

Stoner AW, Waite JM (1990) Distribution and behavior of queen conch Strombus gigas relative to seagrass standing crop. Fish Bull US 88:573-585

Stoner AW, Waite JM (1991) Trophic biology of Strombus gigas in nursery habitats: diets and food sources in seagrass meadows. J Mollusc Stud 57:451-460

This article was submitted to the editor
Summerson HC, Peterson CH (1984) Role of predation in organizing benthic communities of a temperate-zone seagrass bed. Mar Ecol Prog Ser 15:63-77

Thayer GW, Bjorndal KA, Ogden JC, Williams SL, Zieman JC (1984) Role of larger herbivores in seagrass communities. Estuaries 7:351-376

Tribble GW (1981) Reef-based herbivores and the distribution of two seagrasses (Syringodium filiforme and Thalassia testudinum) in the San Blas Islands (Western Caribbean) Mar Biol 65:277-281

Vadas RL, Fenchel T, Ogden JC (1982) Ecological studies on the sea urchin, Lytechninus variegatus, and the algal-seagrass communities of the Miskito Cays, Nicaragua A.quat Bot 14:109-125

van Montfrans J, Wetzel RL, Orth RJ (1984) Epiphyte-grazer relationships in seagrass meadows: consequences for seagrass growth and production. Estuaries 7:289-309

Wicklund RI, Hepp LJ, Wenz GA (1991) Preliminary studies on the early life history of the queen conch, Strombus gigas, in the Exuma Cays, Bahamas. Proc Gulf Caribb Fish Inst 40:283-298

Zieman JC (1974) Methods for the study of the growth and production of turtle grass. Thalassia testudinum König. Aquaculture 4:139-143

Zieman JC, Iverson RI, Ogden JC (1984) Herbivory effects on Thalassia testudinum leaf growth and nitrogen content. Mar Ecol Prog Ser 15:151-158

Zimmerman R, Gibson R, Harrington J (1979) Herbivory and detritivory among gammaridean amphipods from a Florida seagrass community. Mar Biol 54:41-47

Manuscript first received: October 27, 1994

Revised version accepted: January 1, 1995 